\title{
Gecikmiş tanı nedeniyle püerperiumda apandisit: olgu sunumu
}

\section{Delayed diagnosis of appendicitis in puerperium: case report}

\author{
Nevin SAĞSÖZ1*, Ceyhan TAŞDELEN¹, Murat BULANIK², Gökhan KARACA³ \\ 'Kırıkkale Üniversitesi Tıp Fakültesi Kadın Hastalıkları ve Doğum Ana Bilim Dalı, Kırıkkale \\ 2 Zonguldak Devrek Devlet Hastanesi, Zonguldak \\ ${ }^{3}$ Kırıkkale Üniversitesi Tıp Fakültesi Genel Cerrahi Ana Bilim Dalı, Kırıkkale, TÜRKIYE
}

\section{öz}

Lohusalık döneminde ortaya çıkan enfeksiyon ve ağrı gibi nedenlerin sıklıkla gebelik ve doğuma bağlı olduğu kabul edilir. Ancak, diğer önemli nedenlerde akılda tutulmalıdır. Akut apandisit gebelikte obstetrik nedenler dışında, en sık karşılaşılan akut cerrahi gerektiren durumdur. Bu yazıda; püerperal dönemde karın ağrısı, yüksek vücut ısısı ve yüksek C-reaktif protein ile kliniğimize başvuran akut apandisit tanısı alan bir hasta sunuldu ve konu literatür bilgisi eşliğinde tartışıldı.

Anahtar Kelimeler: Püerperium, apandisit, postpartum dönem

\section{ABSTRACT}

Problems such as infection and pain that occur in the puerperium are frequently assumed to be related to pregnancy or delivery. Nevertheless, other important causes should also be kept in mind. Acute appendicitis is the most common nonobstetrics an acute surgical condition in pregnancy. In current report, a patient who had applied to our clinic with abdominal pain, high body temperature and high C-reactive protein in puerperium and diagnosed as acute appendicitis and later performed appendectomy was presented and the topic was discussed along with the literature review.

Keywords: Puerperium, appendicitis, postpartum period

Corresponding Authora: Nevin SAĞSÖZ, MD. Kırıkkale Üniversitesi Tıp Fakültesi Kadın Hastalıkları ve Doğum Ana Bilim Dalı, Yenişehir, Yahşihan, Kırıkkale, TURKEY

e-mail: nevinsagsoz@yahoo.com

Tel: 05055778638

Doi. 10.18663/tjcl.296076

Received 03.03.2017 accepted 15.03.2017 


\section{Giriş}

Akut apandisit, gebelikte en sık non-obsterik akut karın nedenidir [1]. Erken tanı ve tedavi akut apandisit yönetiminde belirleyicidir. Apandisit tanısı, klinik bulguların laboratuvar ve görüntüleme yöntemleri ile desteklenmesi ile konulur [2]. Gebelikte akut apandisit görülme insidansı \% 0,1-0,2'dir ve non obstetrik cerrahi girişimlerin \%25'ini apendektomi oluşturmaktadır [3]. Gebelik sürecinde apandiksin yer değiştirmesi, ultrasonografinin tanısal değerinin azalması ve fizyolojik lökositoz tanı koymayı güçleştirmektedir. Özellikle ilerleyen gebelik haftalarında, ağrıyla tetiklenen uterin kontraksiyonlar doğum eylemi ile karışabilmektedir. Tanı ve tedavinin gecikmesi apandisit komplikasyonlarının gebelikte daha sık görülmesine neden olur. Perfore apandisitlerin üçüncü trimesterde daha sık olması bunun göstergesidir [4-5].

Bu yazıda, sezaryen operasyonu sonrası postpartum dönemde geç dönemde perfore apandisit tanısı konulan ve tedavi edilen bir olgu sunulmuştur.

\section{Olgu Sunumu}

30 yaşında, G1 P0, makat-baş gelişli ikiz gebelik + preterm eylem tanılarıla sezaryen operasyonu yapılan hasta, taburculuğundan 1 ay sonra, 2 gündür olan karın-kasık ağrısı, bulantı ve kusma şikayeti ile acil servise başvurmuş. Acil serviste yapılan değerlendirme sonucu hastaya miyalji tanısıyla non steroid antiinflamatuar tedavisi verilmiş. Şikayetleri devam eden hastanın tekrar acil servise başvurması üzerine acil tıp bölümünce post-partum enfeksiyon, sezaryen sonrası yabancı cisim ön tanıları ile tarafımıza konsülte edilmiş. Hastanın yapılan muayenesinde; batında defans, hassasiyet ve rebound olması nedeniyle hasta hospitalize edildi. Gaz ve gaita çıııı mevcuttu. Kan basıncı 110/70 mmHg, nabızı 90/dk, ateşi 38,5oC idi. Laboratuar bulgularından Hemoglobin: 12,7g/dL, Beyaz Küre (WBC): $10600 / \mu \mathrm{L}, \mathrm{C}$-reaktif protein (CRP): $223 \mathrm{mg} / \mathrm{L}$ olup diğer biyokimya değerleri normal sınırlarda idi. Transvajinal ultrasonda uterus $8,2 \times 7,5 \times 5,2 \mathrm{~cm}$ boyutlarında, endometrium kalınlığı $6 \mathrm{~mm}$, her iki over normal görünümde olup douglasta mayi artışı izlendi. Abdomen ultrasonunda apandiks vizualize edilemeyen, batında mai izlenmeyen hastadan Genel Cerrahi Bölümünden konsültasyon istendi. Ayrıca, olası enfeksiyon için enfeksiyon hastalıkları önerisiyle alınan kan, idrar ve vajen kültürü sonrası siprofloksasin (2x400 mg/200 cc/gün) ve metronidazol (4x\%0,5 IV perfüzyon solüsyonu-100 ml-500 mg/gün) tedavisi başlandı. Bu dönemde CRP değerinin hızla yükseldiği ve $446 \mathrm{mg} / \mathrm{L}$ olduğu gözlendi. Hastaya alt abdomen Bilgisayarlı tomografi (BT) çekildi. BT'de apandiksin sınırları seçilememekle birlikte çapının $15 \mathrm{~mm}$ ölçülmesi; perisplenik alanda, sağ alt kadranda ve pelviste mayi izlenmesi üzerine akut apandisit ön tanısıyla operasyon kararı alındı (Resim 1). Operasyonda perfore apandisit ve yaklaşık 400 cc pürulan mai izlendi; apendektomi ve aspirasyon yapıldı (Resim 2). Hastanın postoperatif 1. gününde laboratuvar değerleri Hemoglobin: 10,5 g/dL, Beyaz Küre (WBC): 6.150 / $\mu \mathrm{L}$, CRP: 267 mg/L idi. Batın içi mai kültüründe E. coli ürediği rapor edildi. Post operatif hastaya meropenem 3x1 gr IV olarak antibiyotik verildi. Hastanın patolojik inceleme sonucu akut flegmanöz apandisit olarak raporlandı. Hasta postoperatif 5. gününde şifa ile taburcu edildi.

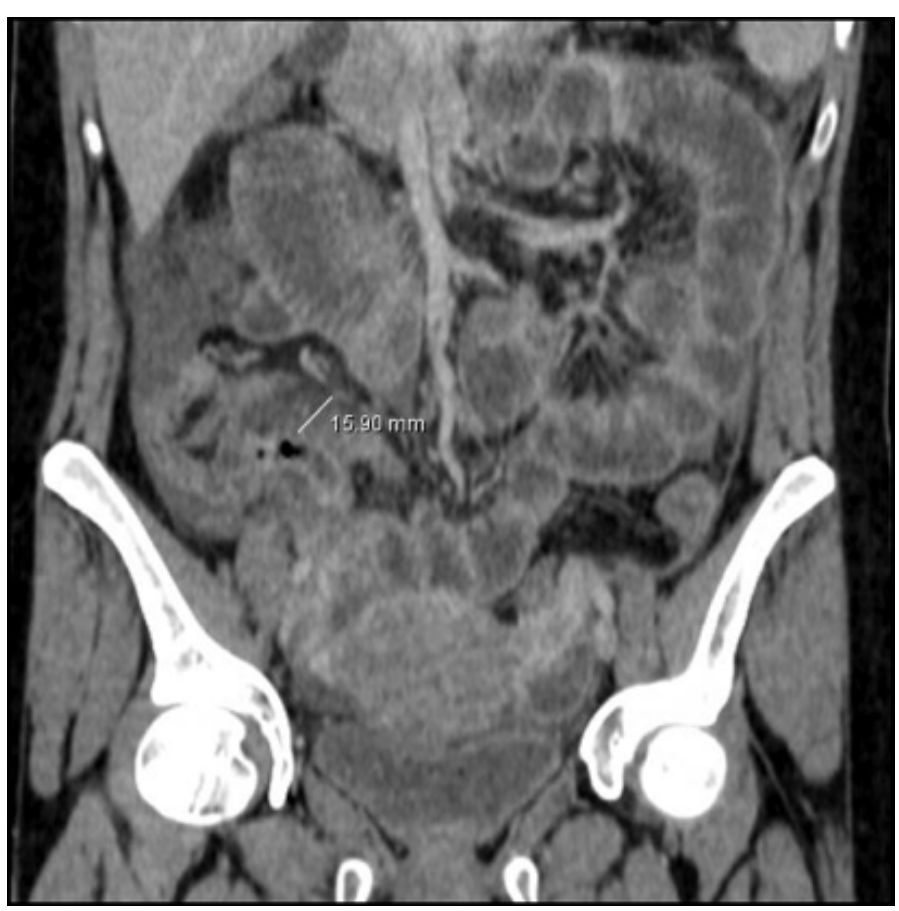

Resim 1. BT'de hastanın apandisitle uyumlu görüntüsü

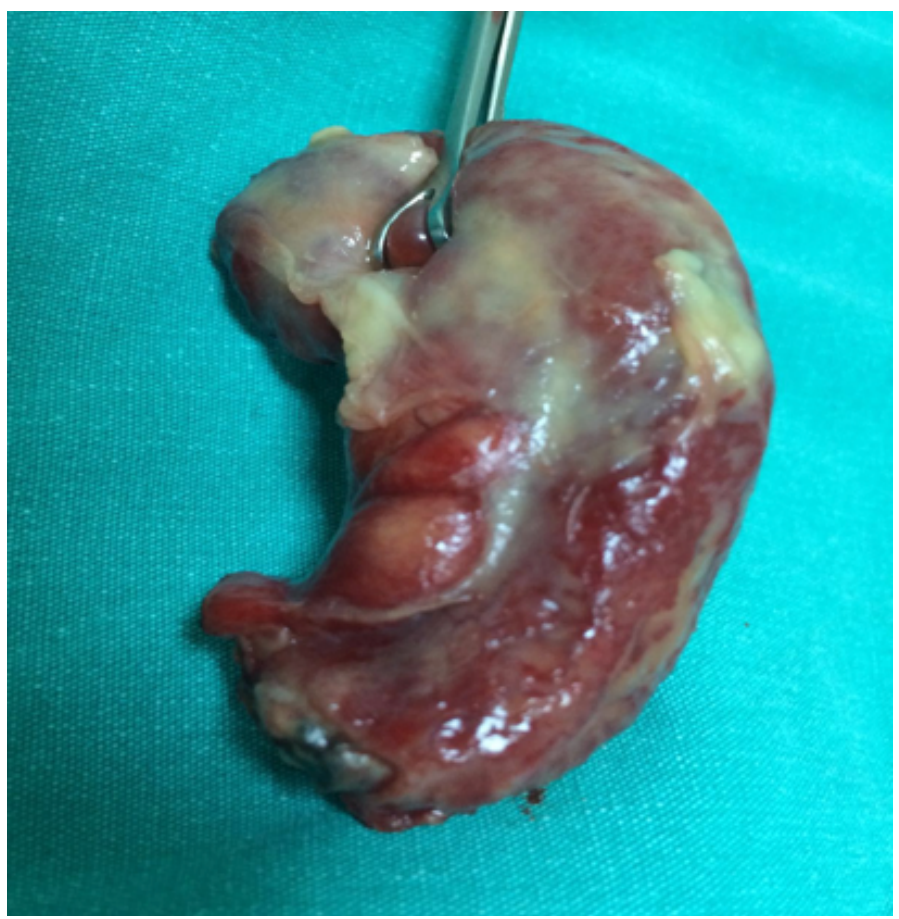

Resim 2. Apendektomi piyesi 


\section{Tartışma}

Akut apandisit tanısı temel olarak anamnez, fizik muayene ve klinik değerlendirme ile konulur [1]. İştahsızlık ilk görülen semptomdur. Bunu, göbek çevresinde başlayıp sağ alt kadrana yayılan karın ağrısı takip eder. Bulantı ve kusma klinik tabloya eşlik edebilir. Akut apandisitli hastaların yaklaşık \%80' inde lökositoz görülür [1]. Görüntüleme yöntemlerinden ultrason, bilgisayarlı tomografi veya manyetik rezonansta apandiks çapının artması ve duvarının kalınlaşması, peri-apendiküler sıvının görülmesi anlamlıdır [6]. Bizim olgumuzda peri apendiküler sıvı mevcut olup apandiks çapının 15 mm ölçülmüş olması tanının konulmasında önemli olmuştur.

Dünya genelinde gebelerin yaklaşık \%2'sine obstetrik olmayan nedenlerle cerrahi girişim yapılmaktadır. Akut apandisit, gebelikte en sık non-obstetrik cerrahi operasyon nedenidir [1]. Gebelikte akut apandisit insidansı artmamakla birlikte apandiksin rübtüre olma olasılığı gecikmiş tanı nedeniyle, 2-3 kat artar [7]. Literatürde gebelikte apandisit ile ilgili bir çok olgu bulunmakla birlikte, postpartum dönemde apandisitle ilgili olgu sayısı sınırIıdır [8-10]. Postpartum dönemde apandisite eşlik eden tipik abdominal ağrılar ve taşikardi sıklıkla yoktur [9]. Püerperiumda abdominal kasların gevşek olması nedeniyle abdominal rijidite ve akut abdomen bulguları olmayabilir. Beyaz küre sayımı ve eritrosit sedimantasyonu normal olarak yüksek olabilir. Bu durum da tanıyı zorlaştırır $[8,9]$. Bizim olgumuzda da acil servise ilk başvurusunda hastada miyalji düşünülmüş ve hastanın kan lökosit sayımı normal olarak gözlenmiştir.

Postpartum dönemde enfeksiyonun kaynağının genellikle doğum ve ürolojik nedenlere bağlı olduğu düşünülür [10]. Bizim olgumuzda da hastanın ağrılarının devam etmesi üzerine hastada sezaryen komplikasyonu ve püerperiumla ilgili sorun düşünülerek hasta tarafımıza yönlendirilmiştir. Hastanın yapılan jinekolojik muayenesinin ve transvajinal ultrasonografik bulgularının normal olması üzerine hasta genel cerrahi konsültasyonu istenmiş ve nedeni bilinmeyen enfeksiyon için antibiyotik verilmiştir ve tomografi sonucu ile hastada akut apandisit düşünülerek hasta opere edilmiştir. Benzer şekilde, literatürde Wadhawan ve ark. püerperal sepsis ve enterik ateş düşünülerek tedavi edilen 2 postpartum apandisit olgusu sunmuşlar ve bilinmeyen sepsis odağı varlığında akut apandisitin akla gelmesi gerektiğini vurgulamışlardır [10]. Bizim olgumuzda yine laboratuvar değerleri incelendiğinde özellikle C-Reaktif proteinin yüksek olduğu ve antibiyotik tedavisine rağmen hızla yükseldiği gözlenmektedir. Kathmandu ve ark. CRP'nin akut apandisit için diagnostik bir marker olduğunu vurgulamışlardır [11].

Perfore apandisitlerin gelişiminde tanıdaki gecikmenin sorumlu olduğu kabul edilmektedir. Vakaların büyük çoğunluğunda perforasyon lokal olarak sınırlanır ve hastada lokalize rebound görülür. Rüptürün etrafını sınırlama işlemi başarısız olursa peritonit tablosu oluşur. Vakaların \%2-5'inde ise inflamasyonlu apandikse bitişik barsak anslarından oluşan flegmonöz apandisit ve peri-apendiküler apse görülür. Bu şekilde bir kitle saptanan hastanın kliniği 5-7 günlük bir süreci kapsar [12]. Bizim vakamızda da hastanın semptomları en az 4-5 gündür var olup, fizik muayenesi ve preoperatif görüntülemesi flegmonöz apandisitle uyumluydu.

Sonuç olarak, akut apandisit erken tanı ve tedavi edilmediği takdirde ciddi morbidite ve mortaliteye neden olabilen bir hastalıktır. Bizim olgumuzda; postpartum dönem karın hassasiyetin myalji olarak değerlendirmesi, hastanın yakın zamanda sezaryen operasyonu olması yüzünden mevcut kliniğinin obstetrik bir komplikasyonla ilişkilendirilmesi tanı koyarken karşılaşılan güçlüklerdir. Akut batın ile başvuran her hastadan detaylı anamnez alınmalı, fizik muayenesi ve tanı araçları dikkatle incelenmelidir. En sık akut karın nedenlerinden olan apandisit akılda tutulmalıdır.

\section{Maddi Destek ve Çıkar İlişkisi}

Çalışmayı maddi olarak destekleyen kişi/kuruluş yoktur ve yazarların çıkara dayalı bir ilişkisi yoktur.

\section{Kaynaklar}

1. Parangi S, Levine D, Henry A, Isakovich N, Pories S. Surgical gastrointestinal disorders during pregnancy. Am J Surg 2007; 19: 223-32.

2. Buckius MT, McGrath B, Monk J, Grim R, Bell T, Ahuja V. Changing epidemiology of acute appendicitis in the United States: study period 1993-2008. J Surg Res 2012; 175: 185-90.

3. Long SS, Long C, Lai H, Macura KJ. Imaging strategies for right lower quadrant pain in pregnancy. Am J Roentgenol 2011; 196: 4-12.

4. Guttman R, Goldman RD, Koren G. Appendicitis during pregnancy. Can Fam Phys Medecin de Famille Canadien 2004; 50: 355-7.

5. Woodfield CA, Lazarus E, Chen KC, Mayo-Smith WW. Abdominal pain in pregnancy: diagnoses and imaging unique to pregnancy-review. Am J Roentgenol 2010; 194: Ws14-Ws30.

6. Old J, Dusing R, Yap W, Dirks J. Imaging for Suspected Appendicitis. Am Fam Phys 2005; 71: 71-8.

7. Zingone F, Sultan AA, Humes DJ, West J. Risk of acute appendicitis in and around pregnancy: a population-based cohort study from England. Ann Surg 2015; 26: 332-7.

8. Milica B, Biljan KK, Tosić V, et al. Appendicitis in puerperium--case report. Acta Chir lugosl 2011; 58: 111-2.

9. Gerstle RK. Postpartum appendicitis presenting as RUQ pain. Am Fam Physician 2008; 77: 282-3.

10. Wadhawan D, Singhal S, Sarda N, Arora R. Appendicitis in Postpartum Period: A Diagnostic Challenge. J Clin Diagn Res 2015; 9: QD10-1.

11. Ghimire R, Sharma A, Bohara S. Role of C-reactive Protein in Acute Appendicitis. Kathmandu Univ Med J (KUMJ) 2016; 54: 130-3.

12. Sleem R, Fisher $S$, Gestring $M$, et al. Perforated appendicitis: is early laparoscopic appendectomy appropriate? Surgery 2009; 146: 731-7 Discussion 737-8. 